\title{
STRATEGI TRAINING WITHIN INDUSTRY SEBAGAI UPAYA PENINGKATAN KEPERCAYAAN DIRI SISWA PADA MATA PELAJARAN PENGOLAHAN MAKANAN KONTINENTAL
}

\author{
Chomzana Kinta Marini \\ Program Keahlian Jasa Boga, SMK Negeri 1 Sewon \\ E-mail: kintamarini@ymail.com
}

\begin{abstract}
Practices in Vocational High Schools hold an important role, because through practices, students could master the skills optimally. Confidence is a significant aspect that should be owned by students to conduct the practices. However in the field, there were several students of grade XI Jasa Boga I of SMKN 1 Sewon who had low confidence in the Continental Cuisine Practice. This was indicated by the hesitation of the students in conducting the practices. Every group depended on the teacher' assistance. This action research was conducted in three cycles that consisted of planning, implementation, observation, and reflection. The results of the study showed an improvement of the students' confidence from 2.49 become 2.66 and 2.86 in the subject of Continental Cuisine through Training within Industry Strategy.
\end{abstract}

Keywords: Confidence, The Strategy of Training within Industry

\begin{abstract}
ABSTRAK
Pembelajaran praktik pada Sekolah Menengah Kejuruan memegang peran yang sangat penting, karena melalui pebelajaran praktik siswa dapat menguasai keterampilan kerja secara optimal. Aspek kepercayaan diri merupakan modal yang harus dimiliki oleh peserta didik dalam mengikuti pembelajaran praktik. Akan tetapi realitanya dalam pembelajaran Pengolahan Masakan Kontinental di kelas XI Jasa Boga 1 SMKN 1 Sewon, masih banyak siswa yang kepercayaan dirinya rendah. Hal ini tampak dari kondisi siswa yang bingung, takut memulai praktik, bahkan hampir semua kelompok menghendaki pendampingan untuk praktik. Penelitian Tindakan Kelas ini dilakukan sebanyak 3 siklus dimulai dari perencanaan tindakan, pelaksanaan, pengamatan dan refleksi. Hasil penelitian menunjukkan bahwa ada peningkatan kepercayaan diri siswa dari skor 2,49 meningkat menjadi 2,66 dan terakhir menjadi 2,86 pada mata pelajaran Pengolahan Masakan Kontinental melalui strategi Training within Industry.
\end{abstract}

Kata kunci: Kepercayaan Diri, Strategi Training within Industry

\section{PENDAHULUAN}

Pendidikan bertujuan untuk menghasilkan lulusan atau sumber daya manusia yang cerdas dan kompetitif. Made Wena (2014: 100) menyatakan bahwa dalam pelaksanaan program pendidikan di Sekolah Menengah Kejuruan maupun pada lembaga pendidikan kejuruan lainnya, pembelajaran praktik memegang peran yang sangat penting. Melalui kegiatan pembelajaran praktik siswa akan dapat menguasai ketrampilan kerja secara optimal.
Realita yang terjadi dalam pembelajaran Pengolahan Masakan Kontinental di kelas XI Jasa Boga 1 SMK Negeri 1 Sewon, masih banyak siswa yang kepercayaan dirinya masih rendah. Hal ini tampak dari kondisi siswa yang tidak segera melakukan praktik tapi mondarmandir berjalan melihat-lihat teman lain kelompok dan saling menunggu padahal sudah diberi jobsheet untuk dipelajari, dijelaskan, bahkan guru telah mendemonstrasikannya. Siswa bingung, ragu-ragu, takut memulai mengerjakan praktik atau tidak percaya diri untuk mengerjakan praktik, sehingga meminta guru untuk 
melakukan tutorial pada masing-masing kelompok atau hampir semua kelompok menghendaki pendampingan untuk praktik, hal ini mengakibatkan suasana kelas mejadi tidak kondusif dan bising.

Nur Ghufron dan Rini Risnawita (2014: 35) menjelaskan bahwa kepercayaan diri adalah keyakinan untuk melakukan sesuatu pada diri subyek sebagai karakteristik pribadi yang di dalamnya terdapat keyakinan akan kemampuan diri, optimis, obyektif, bertanggung jawab, rasional, dan realistis. Siti Nur Dewa (2010: 23) yang mengutip pendapat Rogers mengatakan bahwa kepercayaan diri sebagai kesadaran, kepercayaan seseorang pada kemampuan sendiri dan dapat memanfaatkan secara tepat. Kepercayaan diri digunakan untuk membuat keputusan penilaian-penilaian tanpa harus tergantung pada orang lain. Kepercayaan diri merupakan rasa keyakinan seseorang akan kemampuan dan pengetahuan yang dimilikinya sehingga dapat diaplikasikan pada setiap kegiatan yang dilakukannya. Nirwana (2013: 153) mengatakan bahwa percaya diri merupakan salah satu pangkal dari sikap dan perilaku anak. Percaya diri adalah modal dasar seorang anak dalam memenuhi berbagai kebutuhan dalam hidupnya. Sesuai dengan judul PTK yang akan dilakukan, maka yang dimaksud kepercayaan diri adalah keyakinan yang dimiliki siswa kelas XI Jasa Boga 1 SMKN 1 Sewon, akan potensi diri, kemampuan, dan ketrampilan dalam mengikuti pembelajaran praktik Pengolahan Masakan Kontinental.

Nur Ghufron dan Rini Risnawita (2014: 35) berpendapat bahwa seseorang yang memiliki kepercayaan diri yang tinggi adalah terlihat lebih tenang, tidak memiliki rasa takut, dan mampu memperlihatkan kepercayaan dirinya setiap saat. Siti Nur Dewa (2010: 24) mengatakan bahwa kepercayaan diri sering dikatakan dengan keberanian seseorang untuk melakukan tindakan-tindakan tertentu. Siti Nur Dewa R. (2010: 24) berpendapat bahwa kepercayaan diri seseorang akan berkembang secara perlahan-lahan manakala seseorang merasa mampu melakukan sesuatu karena pengalaman, selanjutnya mampu memetik hikmah dari berbagai pengalaman yang pernah dilalui.

Made Wena (2014: 101-103) mengutip pendapat Nolker \& Schoenfeldt mengatakan bahwa salah satu strategi pembelajaran untuk mengajarkan keterampilan dasar kejuruan adalah strategi pembelajaran industri (Training within Industry) yang terdiri atas 5 tahap kegiatan pembelajaran, yaitu: tahap persiapan, tahap peragaan, tahap peniruan, tahap praktik, dan tahap evaluasi. Apabila tahapan pembelajaran pada strategi ini diterapkan, maka peserta didik akan memperoleh pengalaman melihat, mengamati dan melakukan yang lebih banyak. Berdasarkan uraian di atas maka Penelitian berjudul, "Strategi Training within Industry Sebagai Upaya Peningkatan Kepercayaan Diri Siswa Pada Mata Pelajaran Pengolahan Makanan Kontinental", menarik untuk dilakukan. Rumusan masalah dalam penelitian ini adalah: (1) Bagaimanakah aktivitas siswa dalam implementasi strategi Training within Industry (TWI) pada mata pelajaran Pengolahan Masakan Kontinental pada kelas XI Jasa Boga 1 di SMKN 1 Sewon? (2) Bagaimanakah kepercayaan diri siswa dalam mata pelajaran Pengolahan Masakan Kontinental pada kelas XI Jasa Boga 1 SMKN 1 Sewon? dan (3) Apakah implementasi strategi TWI dapat meningkatkan kepercayaan diri siswa SMKN 1 Sewon dalam pembelajaran Pengolahan Masakan Kontinental?

\section{METODE}

Penelitian yang dilakukan termasuk dalam jenis Classroom Action Research (CAR), atau Penelitian Tindakan Kelas (PTK). Pardjono (2007: 12), menjelaskan bahwa penelitian tindakan kelas adalah salah satu jenis penelitian tindakan yang dilakukan guru untuk meningkatkan kualitas pembelajaran di kelas. Penelitian ini dilakukan untuk meningkatkan kualitas pembelajaran mata pelajaran Pengolahan Masakan Kontinental, dan bertujuan untuk meningkatkan kepercayaan diri siswa dalam pembelajaran mata pelajaran Pengolahan Masakan Kontinental me- 
lalui implementasi strategi Training within Industry (TWI). Prosedur dari penelitian ini adalah menggunakan model Penelitian Tindakan Kelas dari satu siklus yang satu ke siklus yang berikutnya. Setiap siklusnya meliputi empat tahap, yaitu perencanaan (planning), pelaksanaan/tindakan (acting), pengamatan (observation), dan refleksi (reflection).

Penelitian tindakan kelas ini dilaksanakan di SMK Negeri 1 Sewon, yang diintegrasikan pada proses belajar mengajar mata pelajaran Pengolahan Makanan Kontinental. Subyek penelitiannya adalah siswa kelas XI Jasa Boga 1 yang berjumlah 21 orang. Adapun objek penelitiannya adalah implementasi strategi TWI dan kepercayaan diri siswa. Teknik pengumpulan data yang digunakan, yaitu observasi, angket (kuesioner) dan dokumentasi.

Instrumen pengumpulan datanya berupa Lembar Observasi Siswa (LOS), Lembar Observasi Kepercayaan Diri Siswa (LOK), dan Lembar Kepercayaan Diri Siswa (LKDS). Teknik analisis data yang digunakan dalam penelitian tindakan kelas ini adalah analisis deskriptif, jadi data yang diperoleh dari LOS, LOK dan LKDS, disajikan dalam bentuk tabel, disajikan dalam bentuk diagram, kemudian dideskripsikan sebagai mana adanya dan terakhir data dimaknai (diintepretasikan).

\section{HASIL DAN PEMBAHASAN}

Perencanaan siklus 1 yaitu menentukan materi pelajaran, yaitu Kompetendi Dasar: 4.9 Mengolah Hidangan dari Unggas; membuat RPP; menyusun LOS, LOK, dan LKDS; menyiapkan alat dan bahan praktik; menyiapkan media pembelajaran; membuat lembar refleksi guru dan refleksi siswa; dan membuat kartu nomer peserta (name tag).

Pelaksanaan siklus 1, yaitu pelajaran dibuka dengan salam kemudian guru memeriksa kehadiran siswa, dilanjutkan dengan apersepsi dengan mereview pelajaran sebelum- nya. Kemudian dilakukan persiapan yaitu siswa dipandu untuk menata alat dan bahan. Lalu siswa diminta menyiapkan job sheet dan buku catatan serta alat tulis. Setelah kelas terkondisi, guru baru mulai menjelaskan tujuan pembelajaran.

Pada akhir tahap ini, guru menjelaskan bahwa praktik hari ini akan dilaksanakan dengan strategi TWI, kemudian guru menyampaikan tahap-tahapnya. Guru memperagakan cara memilih bahan untuk praktik dan memperagakan cara menggunakan alat yang akan digunakan, dilanjutkan dengan peragaan langkah kerja. Tahap peragaan pada siklus pertama ini nampak berjalan dengan lancar dan rapi, karena semua alat dan bahan sudah dipersiapkan semua sebelum pelajaran dimulai.

Siswa melakukan praktik dengan menirukan apa yang telah diperagakan oleh guru pada tahap sebelumnya, sedang guru mendampingi dan mengarahkan peniruan serta memberikan umpan balik pada hasil kerja siswa. Materi praktik sesuai materi pada job sheet, yaitu Roll Chicken, Prinlaire Vegetable, Qroquette, dan Gravy Sauce. Pada tahap ini siswa nampak bersemangat, senang dan rileks dalam melakukan praktik. Selain itu siswa lebih banyak berada di meja kerja masing-masing, tidak mondar-mandir sebagaimana praktik sebelumnya.

Pada tahap evaluasi guru menilai hasil praktik masing-masing kelompok, kemudian menyampaikan evaluasinya pada siswa baik dari segi proses maupun hasilnya. Siswa diberi kesempatan untuk tanya jawab tentang praktik yang dilaksanakan hari itu. Pada bagian penutup siswa menyampaikan pengalaman, kesalahan, perubahan dan kendala yang dialami selama praktik, serta membuat kesimpulan dengan bimbingan guru. Pengamatan (observation) yang dilakukan kolaborator terhadap kegiatan siswa dalam pembelajaran mata pelajaran Pengolahan Masakan Kontinental, disajikan pada Tabel 1 yang disajikan di bawah ini. 
Tabel 1. Aktivitas Siswa pada Implementasi TWI dalam Mapel PM Kontinental Siklus 1

\begin{tabular}{lccc}
\hline No. & Tahap Pembelajaran & Rerata/Tahap & Kriteria \\
\hline 1 & Persiapan & 2,45 & Sedang \\
2 & Peragaan & 1,91 & Sedang \\
3 & Peniruan & 2,53 & Tinggi \\
4 & Praktik & 2,70 & Tinggi \\
5 & Evaluasi & 2,12 & Sedang \\
& Jumlah Skor & 36,0 & \\
& Rerata & 2,40 & \\
& Kriteria & Sedang & \\
Keterangan Rentang Skor : & $1-1,75$ & $=$ rendah \\
& $1,76-2,50$ & $=$ sedang & \\
& $2,51-3,25$ & $=$ tinggi \\
& $3,26-4,00$ & $=$ sangat tinggi &
\end{tabular}

Berdasarkan data pada Tabel 1 di atas, dapat diketahui bahwa implementasi strategi TWI dalam pembelajaran Pengolahan Masakan Kontinental siklus 1 termasuk dalam kategori sedang/cukup baik dengan jumlah skor 36 dan rerata 2,40 . Jadi pada siklus ini siswa cukup baik, cukup bersemangat dan cukup aktif dalam mengikuti tahap-tahap pembelajaran Pengolahan Masakan Kontinental. Berdasarkan tabel di atas juga dapat diketahui bahwa dari kelima tahap strategi TWI, tiga diantaranya termasuk dalam kriteria sedang, yaitu tahap persiapan, peragaan, dan evaluasi. Sedangkan pada tahap peniruan dan praktik termasuk dalam kriteria tinggi. Terdapat tiga kegiatan dengan skor rendah yaitu pada langkah kelima, siswa tidak ada yang bertanya karena semua tugas kerja dijelaskan dengan rinci oleh guru, dan siswa tidak dilibatkan dalam kegiatan persiapan. Pada langkah ketujuh, siswa juga tidak ada yang bertanya karena guru melaksanakan peragaan dengan sangat runtut akan tetapi siswa tidak dilibatkan pada persiapannya. Pada tahap evaluasi, siswa hanya pasif mengikuti ulasan yang disampaikan guru.

Data kepercayaan diri siswa dalam mengikuti pembelajaran disajikan pada Tabel 2:

Tabel 2. Rekapitulasi Aspek-aspek Kepercayaan Diri Seluruh Siswa Kelas XI JB1 pada Siklus 1

\begin{tabular}{clcccc}
\hline No. & \multicolumn{1}{c}{ Pernyataan } & Rerata Angket & $\begin{array}{c}\text { Rerata } \\
\text { LOK }\end{array}$ & $\begin{array}{c}\text { Rerata/ } \\
\text { Aspek }\end{array}$ & Kriteria \\
\hline 1 & Memiliki harapan besar & 2,29 & 2,43 & 2,36 & Sedang \\
2 & Tidak takut gagal praktik & 2,33 & 2,05 & 2,19 & Sedang \\
3 & Tidak ragu sampaikan ide & 2,48 & 2,14 & 2,31 & Sedang \\
4 & Mandiri & 2,43 & 1,95 & 2,19 & Sedang \\
5 & Mampu Bekerja sama & 2,71 & 3,57 & 3,14 & Tinggi \\
6 & Tidak mudah mengeluh & 2,57 & 2,33 & 2,45 & Sedang \\
7 & Tidak mudah gugup & 2,67 & 2,48 & 2,58 & Tinggi \\
8 & Berani hadapi tantangan & 2,24 & 2,29 & 2,27 & Sedang \\
9 & Mampu menjalin komunikasi & 2,29 & 3,10 & 2,70 & Tinggi \\
10 & Konsentrasi dlm praktik & 2,29 & 3,10 & 2,70 & Tinggi \\
& Jumlah Skor & & & 24,9 & \\
& Rerata & & & 2,49 & \\
& Kriteria & & & & \\
\hline
\end{tabular}

Keterangan Rentang Skor : $1 \quad$ - 1,75= rendah

$1,76-2,50=$ sedang

$2,51-3,25=$ tinggi

$3,26-4,00=$ sangat tinggi 
Berdasarkan Tabel 2 dapat diketahui bahwa kriteria kepercayaan diri siswa pada siklus 1 adalah sedang atau cukup tinggi, dengan jumlah skor 24,9 dan rerata 2,49. Dari 10 aspek yang diamati, terdapat dua aspek yang sudah tinggi yaitu mampu bekerja sama dan tenang tidak mudah gugup. Hal ini mungkin didukung oleh pelaksanaan praktik harian bahkan pada hampir semua mata pelajaran praktik yang banyak dilaksanakan secara berkelompok. Adapun pada aspek kepercayaan diri lainnya masih harus diberi tindakan perbaikan yang tepat agar meningkat. Berikut adalah data kepercayaan diri masing-masing siswa disajikan pada Tabel 3:

Tabel 3. Kepercayaan Diri Per Siswa pada Siklus 1

\begin{tabular}{cccccc}
\hline No. & No. Absen & Rerata Angket & Rerata LOK & Rata-Rata & Kriteria \\
\hline 1 & 1 & 2,30 & 2,10 & 2,20 & Sedang \\
2 & 6 & 2,40 & 2,00 & 2,20 & Sedang \\
3 & 7 & 3,00 & 3,00 & 3,00 & Tinggi \\
4 & 9 & 3,00 & 3,10 & 3,05 & Tinggi \\
5 & 10 & 2,90 & 2,80 & 2,85 & Tinggi \\
6 & 12 & 2,90 & 3,20 & 3,05 & Tinggi \\
7 & 13 & 2,90 & 3,00 & 2,95 & Tinggi \\
8 & 14 & 1,50 & 1,50 & 1,50 & Rendah \\
9 & 15 & 3,00 & 3,10 & 3,05 & Tinggi \\
10 & 16 & 2,30 & 2,10 & 2,20 & Sedang \\
11 & 17 & 2,90 & 3,20 & 3,05 & Tinggi \\
12 & 18 & 2,90 & 2,90 & 2,90 & Tinggi \\
13 & 19 & 1,10 & 1,30 & 1,20 & Rendah \\
14 & 20 & 3,00 & 3,00 & 3,00 & Tinggi \\
15 & 22 & 2,10 & 2,10 & 2,10 & Sedang \\
16 & 23 & 2,00 & 2,20 & 2,10 & Sedang \\
17 & 24 & 2,70 & 3,00 & 2,85 & Tinggi \\
18 & 25 & 1,40 & 1,40 & 1,40 & Rendah \\
19 & 27 & 2,80 & 2,90 & 2,85 & Tinggi \\
20 & 29 & 2,50 & 2,20 & 2,35 & Sedang \\
21 & 30 & 1,40 & 1,30 & 1,35 & Rendah \\
Jumlah & Skor & & & 51,2 & \\
Rerata & & & & 2,44 & \\
Kriteria & & & Sedang & \\
\hline
\end{tabular}

Keterangan Rentang Skor : $1 \quad-1,75=$ rendah

$$
\begin{aligned}
& 1,76 \quad-2,50=\text { sedang } \\
& 2,51 \quad-3,25=\text { tinggi } \\
& 3,26-4,00=\text { sangat tinggi }
\end{aligned}
$$

Berdasarkan data yang disajikan di atas dapat diketahui bahwa kepercayaan diri siswa pada siklus 1 termasuk kategori sedang dengan jumlah skor 51,2 dan rerata 2,44. Dari 21 orang siswa yang memiliki kepercayaan diri sangat tinggi tidak ada, kategori tinggi $11(52,4 \%)$ orang, kategori sedang $(28,6 \%)$ orang, dan rendah $4(19 \%)$ orang. Jadi siswa yang kepercayaan dirinya baik dan sangat baik adalah 11 orang (52,4\%). Angka ini masih lebih rendah bila dibandingkan dengan indikator kinerja yang ditentukan pada penelitian ini minimal 80\% siswa memiliki kepercayaan diri tinggi/baik. Dengan demikian penelitian dilanjutkan ke siklus dua dengan perlakukan perbaikan terhadap kekurangan yang terjadi pada siklus 1 .

Jumlah siswa berdasarkan tingkat kepercayaan diri pada siklus 1 ditunjukan pada Gambar 1. 


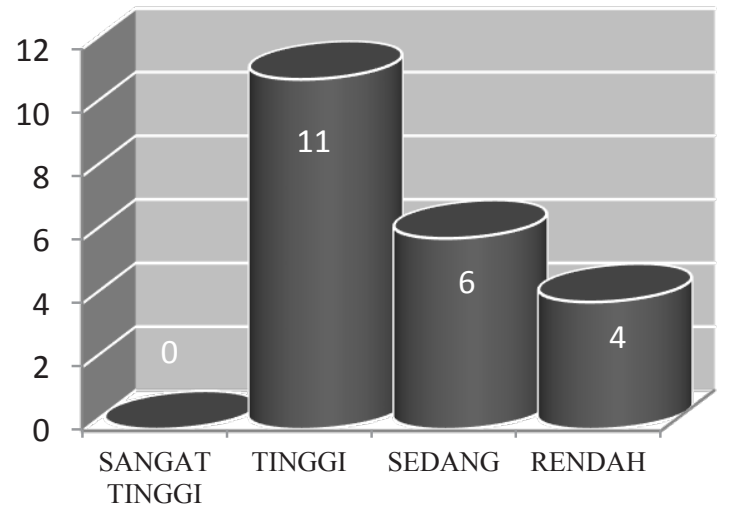

\section{Gambar 1. Jumlah Siswa Berdasarkan Tingkat Kepercayaan Diri Siklus 1}

Pada tahap refleksi, peneliti melakukan kajian terhadap pelaksanaan implementasi strategi TWI, aktivitas siswa dalam mengikuti pembelajaran dan dampak tindakan pembelajaran menggunakan strategi TWI terhadap perubahan kepercayaan diri siswa. Langkah selanjutnya adalah membandingkan hasil pengamatan pelaksanaan implementasi strategi TWI dan perubahan kepercayaan diri siswa dengan indikator kinerja yang telah ditentukan.

Berdasarkan hasil observasi yang dilaksanakan menunjukkan bahwa strategi TWI dapat meningkatkan kepercayaan diri siswa dalam pembelajaran Pengolahan Masakan Kontinental, juga meningkatkan kualitas pembelajaran Pengolahan Masakan Kontinental pada umumnya. Secara garis besar, peningkatan kepercayaan diri siswa ini jauh meningkat dibandingkan kondisi sebelum tindakan diterapkan, akan tetapi indikator kinerja yang ditetapkan belum tercapai. Oleh karena itu, penelitian tindakan kelas ini perlu dilanjutkan pada siklus kedua dengan melakukan perbaikan terhadap kekurangan-kekurangan yang teridentifikasi pada siklus pertama.

Secara lebih rinci, refleksi terhadap pelaksanaan siklus 1 adalah sebagai berikut: (1) Pada tahap persiapan sampai pada peniruan, tidak ada siswa yang mengajukan pertanyaan meskipun diberi kesempatan untuk bertanya; (2) Persiapan bahan dan alat pada siklus ini sangat baik karena ditangani sendiri oleh guru beserta tiga orang siswa yang ditunjuk, jadi tidak semua siswa terlibat di dalamnya; dan (3) Evaluasi hanya dilakukan oleh guru, yaitu dengan menilai hasil praktik sesuai kriteria hasil yang sudah ditetapkan, kemudian guru memberikan umpan balik proses dan hasil praktik kepada siswa.

Berdasarkan refleksi yang telah dilakukan, maka tindakan perbaikan yang akan diterapkan pada siklus yang kedua adalah: (1) Meningkatkan persentase keterlibatan siswa pada proses persiapan alat dan bahan praktik, sehingga penguasaan materi pelajaran sudah dapat dimulai sejak dini, dan pengalaman belajar yang diperoleh siswa menjadi lebih banyak. Dengan melakukan persiapan praktik, maka semakin banyak juga kesulitan, hambatan, dan pertanyaan yang akan muncul dalam menyelesaikan tugas tersebut. Selain itu dengan melibatkan siswa, beban guru menjadi lebih ringan; dan (2) Merencanakan untuk memberi tugas kepada siswa untuk mempresentasikan hasil pada tahap evaluasi.

Perencanaan siklus 2 yaitu menentukan materi pelajaran, yaitu Kompetensi Dasar: 4.11 Membuat Hidangan dari Seafood; membuat RPP; menyusun LOS, LOK, dan LKDS; menyiapkan alat dan bahan praktik; menyiapkan media pembelajaran; membuat lembar refleksi guru dan refleksi siswa; dan membuat kartu nomer peserta (name tag).

Pelajaran dibuka dengan salam kemudian guru memeriksa kehadiran siswa, dan dilanjutkan dengan apersepsi dengan mereview pelajaran sebelumnya. Persiapan dilakukan siswa dipandu oleh guru yaitu untuk mengidentifikasi kebutuhan alat dan bahan praktik berdasarkan job sheet yang dibagikan. Selanjutnya siswa diminta mengambil alat dan bahan praktik sendiri. Setelah siswa meletakkan alat dan bahan praktik di meja masing-masing, maka siswa diberi waktu untuk membaca job sheet, sembari guru mempersiapkan diri. Setelah kelas terkondisi, guru baru mulai menjelaskan tujuan pembelajaran, dan menjelaskan materi praktik. Pada akhir tahap ini, guru kembali menjelaskan bahwa praktik hari itu akan dilaksanakan dengan 
strategi TWI, kemudian guru menyampaikan tahap-tahapnya.

Guru memperagakan cara memilih bahan untuk praktik, juga memperagakan cara menggunakan alat spesifik yang akan digunakan, dilanjutkan dengan peragaan langkah kerja. Tahap ini dilakukan pada semua menu yang akan dipraktikkan. Siswa diijinkan untuk mengajukan pertanyaan pada saat pun pada akhir peragaan. Peniruan yaitu siswa melakukan praktik dengan menirukan apa yang telah diperagakan oleh guru pada tahap sebelumnya, sedang guru mendampingi dan mengarahkan peniruan serta memberikan balikan pada hasil kerja siswa. Siswa melakukan praktik sesuai materi pada job sheet, yaitu Crab Farci with Hollandaise Sauce, Pommes Parisienne.

Pada tahap evaluasi guru menilai hasil praktik, kemudian menyampaikan evaluasinya secara umum pada siswa. Setelah itu beberapa siswa yang ditunjuk diberi tugas untuk mem- presentasikan hasil praktiknya. Hal ini dilakukan sesuai dengan hasil refleksi siklus pertama antara guru dengan kolaborator, yang bertujuan untuk membangkitkan keaktifan siswa dalam tahap evaluasi. Dampak dari stimuli ini adalah beberapa siswa yang semula pasif diberi kesempatan untuk mempresentasikan hasil praktiknya. Tahap evaluasi diakhiri dengan ulasan dari guru atas presentasi yang disampaikan dan penyampaian nilai praktik. Penutupan diisi dengan siswa menyampaikan pengalaman, kesalahan, perubahan dan kendala yang dialami selama praktik, serta membuat kesimpulan dengan bimbingan guru, dilanjutkan berkemas.

Hasil pengamatan kolaborator terhadap kegiatan siswa dalam mengikuti pembelajaran Pengolahan Masakan Kontinental dengan mengimplementasikan strategi TWI, disajikan pada Tabel 4 berikut:

Tabel 4. Rekapitulasi Aspek-aspek Kepercayaan Diri Seluruh Siswa Kelas XI JB1 pada Siklus 2

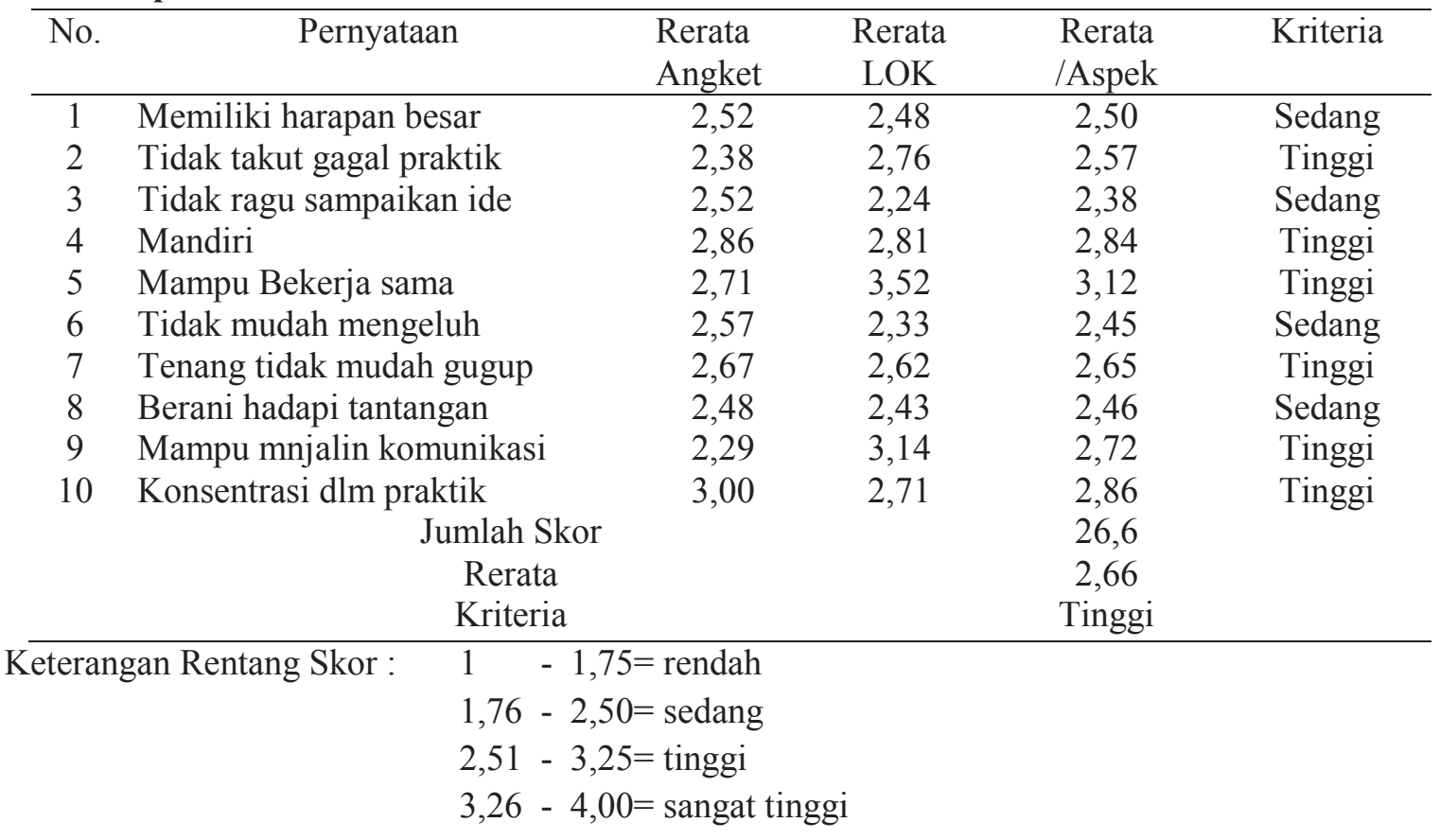

Berdasarkan data Tabel 4 dapat diketahui bahwa kriteria kepercayaan diri siswa pada siklus 2 adalah tinggi, dengan jumlah skor 26,6 dan rerata 2,66. Dari 10 aspek yang diamati, terdapat enam aspek yang sudah tinggi yaitu tidak takut gagal praktik, mandiri, mampu bekerjasama, tenang tidak mudah gugup, mampu menjalin komunikasi dan konsentrasi dalam praktik. Sedang aspek kepercayaan diri lainnya juga mengalami kenaikan, jadi tindakan 
perbaikan yang dilakukan pada siklus 2 sudah tepat. Namun demikian tentu pembelajaran ini masih harus ditingkatkan hasilnya. Data kepercayaan diri masing-masing siswa pada siklus 2 disajikan pada Tabel 5 berikut ini.

Tabel 5. Kepercayaan Diri Per Siswa pada Siklus 2

\begin{tabular}{rrcrrr}
\hline No & No.Absen & Rerata Angket & Rerata LOK & Rata-Rata & Kriteria \\
\hline 1 & 1 & 2,50 & 2,30 & 2,40 & Sedang \\
2 & 6 & 2,60 & 2,30 & 2,45 & Sedang \\
3 & 7 & 3,30 & 3,10 & 3,20 & Tinggi \\
4 & 9 & 3,00 & 3,30 & 3,15 & Tinggi \\
5 & 10 & 3,00 & 2,90 & 2,95 & Tinggi \\
6 & 12 & 3,00 & 3,40 & 3,20 & Tinggi \\
7 & 13 & 3,00 & 3,20 & 3,10 & Tinggi \\
8 & 14 & 2,00 & 1,90 & 1,95 & Sedang \\
9 & 15 & 3,10 & 3,30 & 3,20 & Tinggi \\
10 & 16 & 2,60 & 2,30 & 2,45 & Sedang \\
11 & 17 & 3,20 & 3,30 & 3,25 & Tinggi \\
12 & 18 & 3,00 & 3,10 & 3,05 & Tinggi \\
13 & 19 & 1,60 & 1,60 & 1,60 & Rendah \\
14 & 20 & 3,10 & 3,10 & 3,10 & Tinggi \\
15 & 22 & 2,20 & 2,60 & 2,40 & Sedang \\
16 & 23 & 2,20 & 2,40 & 2,30 & Sedang \\
17 & 24 & 2,70 & 3,10 & 2,90 & Tinggi \\
18 & 25 & 1,50 & 2,20 & 1,85 & Sedang \\
19 & 27 & 2,90 & 3,10 & 3,00 & Tinggi \\
20 & 29 & 2,60 & 2,70 & 2,65 & Tinggi \\
21 & 30 & 1,50 & 1,60 & 1,55 & Rendah \\
& & Jumlah Skor & & 55,7 & \\
& & Rerata & & 2,65 & \\
\hline
\end{tabular}

Berdasarkan data Tabel 5 tersebut dapat diketahui bahwa kepercayaan diri siswa pada siklus 2 termasuk kategori tinggi dengan jumlah skor 55,7 dan rerata 2,65. Dari 21 orang siswa yang memiliki kepercayaan diri sangat tinggi tidak ada, kategori tinggi sebesar 57\%, kategori sedang sebesar $33 \%$, dan rendah sebesar $10 \%$. Jadi siswa yang kepercayaan dirinya baik dan sangat baik adalah sebesar 57\%. Angka ini masih lebih rendah bila dibandingkan dengan indikator kinerja yang ditentukan pada penelitian ini minimal $80 \%$ siswa memiliki kepercayaan diri tinggi/baik. Dengan demikian penelitian dilanjutkan ke siklus tiga dengan tindakan perbaikan terhadap kekurangan yang ada pada siklus 2. Jumlah siswa berdasarkan tingkat kepercayaan diri pada siklus 2 ditunjukkan pada Gambar 2.

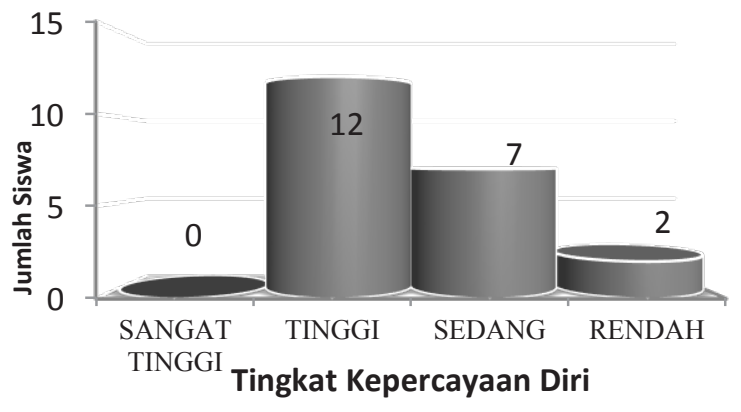

Gambar 2. Jumlah Siswa Berdasarkan Tingkat Kepercayaan Diri Siklus 2

Berdasarkan hasil observasi yang dilaksanakan menunjukkan bahwa implementasi strategi TWI yang sudah diperbaiki pada siklus 2 ini dapat lebih meningkatkan kepercayaan diri siswa dalam pembelajaran Pegolahan Masakan Kontinental. Secara garis besar, kepercayaan diri siswa menjadi lebih baik dibandingkan pada 
siklus kedua, dan mendekati indikator kinerja yang telah ditetapkan. Oleh karena itu, penelitian tindakan kelas ini perlu dilanjutkan pada siklus ketiga dengan melakukan perbaikan terhadap kekurangan-kekurangan yang teridentifikasi pada siklus kedua. Adapun kekurangan yang terjadi pada pelaksanaan pembelajaran siklus 2 yang perlu diperbaiki adalah sebagai berikut: (1) Kurangnya waktu yang diberikan untuk membaca lembar kerja, sehingga siswa terlalu mengandalkan informasi materi yang akan dipraktikkan dari guru. Akibatnya siswa menjadi kurang komunikatif dalam menanggapi penjelasan guru (2) Pada tahap peragaan, siswa sering harus menunggu lama untuk selesainya peragaan, karena adanya banyak proses dalam satu masakan. Hal ini juga sangat mengganggu konsentrasi siswa, dan memerlukan waktu yang lebih lama. Untuk mempercepat peragaan maka sebaiknya ada beberapa proses dalam memasak suatu masakan yang dipersiapkan sebelumnya (preparation), yaitu pada proses yang sudah diajarkan dan dikuasai siswa pada pembelajaran sebelumnya. Contoh kegiatan seperti membuat kaldu (stock), mencincang sayuran, mencairkan mentega.

Perencanaan pada siklus ketiga dilakukan dengan menentukan materi pelajaran, yaitu Kompetensi Dasar: 4.7 Membuat hidangan dari sayuran dan telur; membuat RPP; menyusun LOS, LOK, dan LKDS; menyiapkan alat dan bahan praktik; menyiapkan media pembelajaran; membuat lembar refleksi guru dan refleksi siswa; dan membuat kartu nomer peserta (name tag). Pendahuluan dilakukan dengan membuka pelajaran dengan salam kemudian guru memeriksa kehadiran siswa. Selanjutnya guru memeriksa kehadiran siswa dan dilanjutkan dengan apersepsi dengan mereview pelajaran sebelumnya. Tahap persiapan yaitu memandu siswa untuk menata alat dan bahan praktik yang sudah dipersiapkan oleh dua siswa yang ditunjuk sebelumnya. Kemudian seluruh siswa diminta menyiapkan job sheet dan buku catatan serta alat tulis. Setelah kelas terkondisi, guru mulai menjelaskan tujuan pembelajaran dan materi. Selain itu juga dilakukan diskusi dalam memahami materi praktik. Pada akhir tahap ini, guru menjelaskan bahwa praktik hari ini akan dilaksanakan dengan strategi TWI.

Tahap peragaan, yaitu guru memperagakan cara memilih bahan untuk praktik, juga memperagakan cara menggunakan alat spesifik yang akan digunakan, dilanjutkan dengan peragaan langkah kerja. Tahap ini dilakukan pada semua menu yang akan dipraktikkan.

Tahap peniruan, siswa menirukan apa yang telah diperagakan oleh guru pada tahap sebelumnya, sedang guru mendampingi dan mengarahkan serta memberikan umpan balik pada hasil kerja siswa. Setelah peniruan, siswa mempraktikkan menu Poached Egg Florentine, Sauted Spinach, Mashed Potatoes, dan Mornay Sauce.

Tahap evaluasi guru menilai hasil praktik masing-masing kelompok, kemudian menyampaikan evaluasi secara umum pada siswa baik dari segi proses maupun hasilnya. Setelah itu setiap kelompok harus mempresentasikan hasil praktiknya, dan pada gilirannya harus menanggapi presentasi hasil praktik dari kelompok lain. Hal ini dilakukan sesuai dengan hasil refleksi siklus kedua antara guru dengan kolaborator, yang bertujuan untuk meningkatkan keaktifan siswa dalam tahap evaluasi.

Sebelum pelajaran diakhiri maka siswa diminta menyampaikan pengalaman, kesalahan, perubahan dan kendala yang dialami selama praktik, serta membuat kesimpulan dengan bimbingan guru. Dilanjutkan kegiatan berkemas. Hasil pengamatan kolaborator terhadap kegiatan siswa dalam mengikuti pembelajaran Pengolahan Masakan Kontinental dengan mengimplementasikan strategi Training within Industri, disajikan pada Tabel 6 di bawah ini. 
Tabel 6. Aktivitas Siswa pada Implementasi Strategi TWI dalam Siklus 3

\begin{tabular}{cccc}
\hline No. & Tahap Pembelajaran & Rerata/Tahap & Kriteria \\
\hline 1 & Persiapan & 2,89 & Tinggi \\
2 & Peragaan & 2,62 & Tinggi \\
3 & Peniruan & 2,63 & Tinggi \\
4 & Praktik & 2,81 & Tinggi \\
5 & Evaluasi & 2,86 & Tinggi \\
& Jumlah Skor & 13,8 & \\
Rerata & 2,78 & \\
Kriteria & Tinggi & \\
Keterangan Rentang Skor: & $1-1,75$ & $=$ rendah & \\
& $1,76-2,50$ & $=$ sedang & \\
& $2,51-3,25$ & $=$ tinggi &
\end{tabular}

Berdasarkan data-data yang tersaji pada Tabel 6 di atas, dapat diketahui bahwa implementasi strategi TWI dalam pembelajaran Pengolahan Masakan Kontinental siklus 3 termasuk dalam kategori tinggi dengan jumlah skor 41,5 dan rerata 2,78 . Jadi pada siklus ini aktivitas siswa tinggi, bersemangat dan aktif mengikuti tahap-tahap strategi TWI pembelajaran Pengolahan Masakan Kontinental. Berdasarkan tabel di atas juga dapat diketahui bahwa dari kelima tahap strategi TWI, seluruhnya terlaksana dengan kriteria tinggi. Pada siklus 3 ini prosentase keterlibatan siswa dalam persiapan makin meningkat. Yaitu siswa diberi tugas membuat daftar kebutuhan alat dan bahan untuk masing-masing menu yang akan dipraktikkannya, dilanjutkan mengambil dan mempersiapkan sendiri alat dan bahan praktik tersebut. Guru memberikan waktu yang lebih banyak bagi siswa untuk membaca dan memahami job sheet. Pada tahap evaluasi, seluruh siswa diberi tugas untuk mempresentasikan hasil masakan, sementara teman yang lain diberi tugas untuk menanggapinya. Dengan demikian keaktifan siswa dalam pembelajaran meningkat, jadi kepercayaan diri siswa juga meningkat. Data kepercayaan diri siswa dalam mengikuti pembelajaran Pengolahan Masakan Kontinental, disajikan pada Tabel 7 berikut:

Tabel 7. Rekapitulasi Aspek-aspek Kepercayaan Diri Seluruh Siswa pada Siklus 3

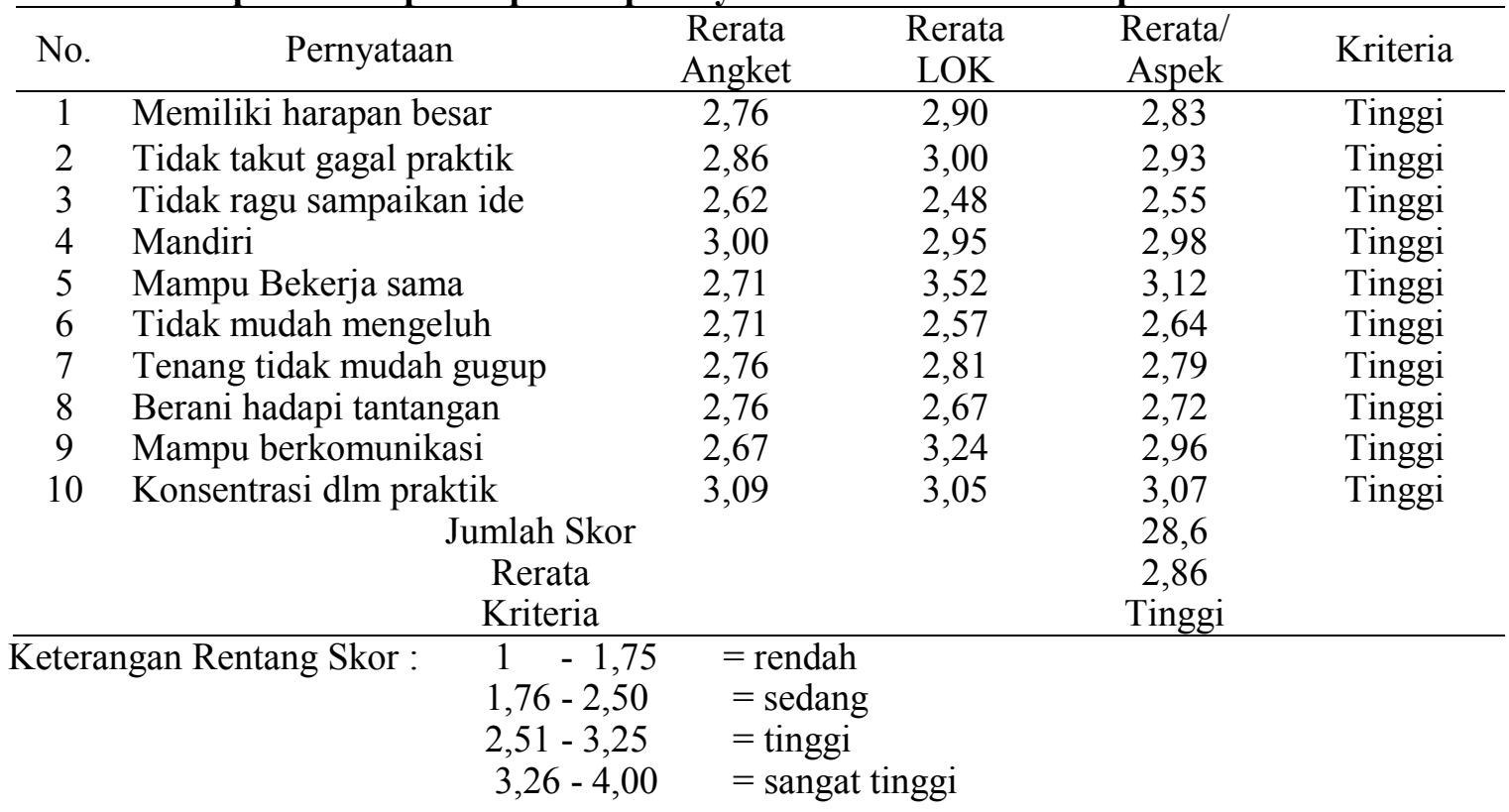


Berdasarkan Tabel 7 tersebut dapat diketahui bahwa kriteria kepercayaan diri siswa pada siklus 3 adalah tinggi, dengan jumlah skor 28,6 dan rerata 2,86. Dari 10 aspek kepercayaan diri yang diamati, seluruhnya termasuk dalam kriteria baik. Hal ini berarti bahwa dalam mengikuti praktik mata pelajaran Pengolahan Masakan Kontinental siswa memiliki harapan yang tinggi, tidak takut gagal praktik, mandiri, mampu bekerja sama, tenang tidak mudah gugup, mampu menjalin komunikasi dan konsentrasi dalam praktik. Jadi tindakan perbaikan yang dilakukan pada siklus ketiga sudah tepat, sehingga dapat meningkatkan tingkat kepercayaan diri siswa. Data tingkat kepercayaan siswa disajikan pada Tabel 8 di bawah ini.

Tabel 8. Kepercayaan Diri Per Siswa pada Siklus 3

\begin{tabular}{cccccc}
\hline No. & No Absen & Rerata Angket & Rerata LOK & Rata-Rata & Kriteria \\
\hline 1 & 1 & 2,60 & 2,70 & 2,65 & Tinggi \\
2 & 6 & 2,80 & 2,60 & 2,70 & Tinggi \\
3 & 7 & 3,30 & 3,20 & 3,25 & Tinggi \\
4 & 9 & 3,00 & 3,30 & 3,15 & Tinggi \\
5 & 10 & 3,00 & 2,90 & 2,95 & Tinggi \\
6 & 12 & 3,00 & 3,50 & 3,25 & Tinggi \\
7 & 13 & 3,00 & 3,20 & 3,10 & Tinggi \\
8 & 14 & 2,30 & 2,20 & 2,25 & Sedang \\
9 & 15 & 3,10 & 3,30 & 3,20 & Tinggi \\
10 & 16 & 2,90 & 2,60 & 2,75 & Tinggi \\
11 & 17 & 3,20 & 3,40 & 3,30 & Sangat Tinggi \\
12 & 18 & 3,00 & 3,20 & 3,10 & Tinggi \\
13 & 19 & 2,30 & 2,30 & 2,30 & Sedang \\
14 & 20 & 3,10 & 3,10 & 3,10 & Tinggi \\
15 & 22 & 2,60 & 2,80 & 2,70 & Tinggi \\
16 & 23 & 2,50 & 2,80 & 2,65 & Tinggi \\
17 & 24 & 2,90 & 3,20 & 3,05 & Tinggi \\
18 & 25 & 2,00 & 2,50 & 2,25 & Sedang \\
19 & 27 & 2,90 & 3,10 & 3,00 & Tinggi \\
20 & 29 & 2,80 & 3,00 & 2,90 & Tinggi \\
21 & 30 & 2,40 & 2,40 & 2,40 & Sedang \\
Jumlah skor & & & & 60 & \\
Rerata & & & & 2,86 & \\
Kriteria & & & & Tinggi & \\
\hline
\end{tabular}

Keterangan Rentang skor : $1-1,75=$ rendah

$1,76-2,50=$ sedang

$2,51-3,25=$ tinggi

$3,26-4,00=$ sangat tinggi

Pada Tabel 8 di atas dapat diketahui bahwa kepercayaan diri siswa pada siklus ketiga termasuk kategori tinggi dengan jumlah skor 60 dan rerata 2,86. Siswa yang memiliki kepercayaan diri sangat tinggi sebanyak 1 orang (5\%), kategori tinggi sebanyak 16 orang $(76 \%)$, kategori sedang sebanyak 4 orang (19\%), dan rendah tidak ada. Jumlah siswa yang kepercayaan dirinya baik dan sangat baik pada siklus 3 ini adalah sebanyak 17 orang (81\%). Angka ini lebih besar dibandingkan dengan indikator kinerja yang ditentukan pada penelitian ini, yaitu minimal $80 \%$ siswa memiliki kepercayaan diri tinggi. Dengan demikian penelitian tindakan kelas ini sudah dikatakan berhasil memperbaiki pembelajaran Pengolahan Masakan Kontinental. Jumlah siswa berdasarkan tingkat kepercayaan 
diri pada siklus ketiga ditunjukkan pada Gambar 3.

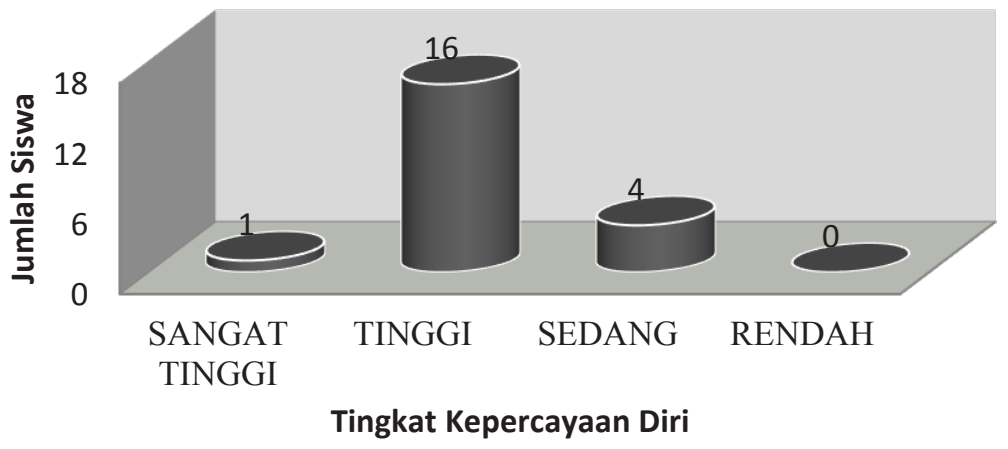

Gambar 3.Diagram Batang Kepercayaan Diri Siswa Siklus 3

Rekapitulasi seluruh aktivitas siswa berupa rata-rata hasil tahapan pembelajaran siswa pada siklus 1, 2 dan 3 disajikan pada Tabel 9. Berdasarkan data pada Tabel 9 tersebut menunjukkan bahwa aktivitas siswa dalam mengikuti pembelajaran sejak siklus 1 hingga 3 mengalami peningkatan. Sehingga dapat dikatakan bahwa pembelajaran dengan strategi TWI dapat diikuti dengan makin baik, makin aktif dan makin bersemangat dari waktu ke waktu.

Tabel 9. Rekapitulasi Aktivitas Siswa dalam Pembelajaran dengan Strategi TWI

\begin{tabular}{|c|c|c|c|c|c|}
\hline \multirow{2}{*}{ No. } & \multirow{2}{*}{ Tahap Pembelajaran } & \multicolumn{3}{|c|}{ Rerata } & \multirow[t]{2}{*}{ Keterangan } \\
\hline & & Siklus 1 & Siklus 2 & Siklus 3 & \\
\hline 1. & Persiapan & 2,45 & 2,68 & 2,89 & Meningkat \\
\hline 2. & Peragaan & 1,91 & 2,55 & 2,62 & Meningkat \\
\hline 3. & Peniruan & 2,53 & 2,53 & 2,63 & Meningkat \\
\hline 4. & Praktik & 2,70 & 2,68 & 2,81 & Meningkat \\
\hline & Evaluasi & 2,12 & 2,76 & 2,76 & Meningkat \\
\hline \multicolumn{2}{|c|}{ Jumlah Skor } & 36 & 39,6 & 41,5 & Meningkat \\
\hline \multicolumn{2}{|c|}{ Rerata } & 2,40 & 2,64 & 2,78 & Meningkat \\
\hline \multicolumn{2}{|c|}{ Kriteria } & Sedang & Tinggi & Tinggi & \\
\hline
\end{tabular}

Keterangan Rentang Skor: $1-1,75=$ rendah

$1,76-2,50=$ sedang

$2,51-3,25=$ tinggi

$3,26-4,00=$ sangat tinggi

Rekapitulasi tingkat kepercayaan diri siswa dalam pembelajaran Pengolahan Masakan Kontinental dengan implementasi strategi TWI, pada siklus 1, 2 dan 3 ditunjukkan pada Tabel 10 di bawah ini.

Tabel 10. Rekapitulasi Kepercayaan Diri Siswa Siklus 1, 2, dan 3

\begin{tabular}{clcccc}
\hline No. & Kriteria & Siklus 1 & Siklus 2 & Siklus 3 & Keterangan \\
\hline 1. & Sangat Tinggi & 0 & 0 & $4,7 \%$ & Secara keseluruhan \\
2. & Tinggi & $52,4 \%$ & $57,1 \%$ & $76,2 \%$ & kepercayaan diri \\
3. & Sedang & $28,6 \%$ & $33,3 \%$ & $19,1 \%$ & siswa meningkat \\
4. & Rendah & $19 \%$ & $9,6 \%$ & 0 & \\
& Total & $100 \%$ & $100 \%$ & $100 \%$ & \\
\hline
\end{tabular}


Berdasaran data pada Tabel 10 di atas dapat diketahui bahwa tingkat kepercayaan diri siswa dari siklus 1 ke siklus 2 lalu ke siklus 3, terus mengalami kenaikan, yang mengandung arti bahwa siswa memiliki harapan yang besar, tidak takut gagal dalam praktik, tidak ragu dalam menyampaikan ide, mandiri, mampu bekerja sama, tidak mudah mengeluh, tidak mudah gugup, berani menghadapi tantangan, mampu menjalin komunikasi dan konsentrasi dalam mengikuti pembelajaran Pengolahan Masakan Kontinental. Gambar 4 berikut ini menjelaskan rekapitulasi kepercayaan diri siswa pada siklus 1,2, dan 3:

- Siklus 1 Siklus 2 Siklus 3

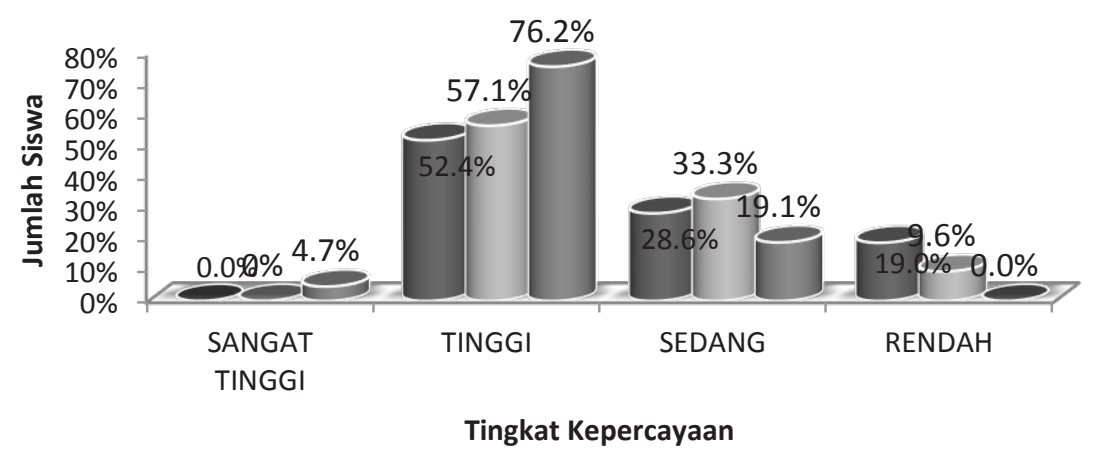

\section{Gambar 4. Rekapitulasi Tingkat Keperayaan Diri Siswa} pada Siklus 1, 2, dan 3

Penelitian tindakan kelas ini dilaksanakan dalam rangka memperbaiki pembelajaran Pengolahan Masakan Kontinental yang dirasakan kurang optimal dikarenakan ada beberapa permasalahan yang diduga disebabkan karena rendahnya kepercayaan diri siswa. Selanjutnya, penelitian ini akan dikatakan berhasil bila indikator kinerja yang ditetapkan sebagai target telah terpenuhi. Adapun indikator kinerja dalam penelitian ini adalah bila minimal $80 \%$ siswa memiliki kepercayaan diri kriteria tinggi/baik, maka penelitian ini dikatakan berhasil. Berikut adalah rekapitulasi ketercapaian indikator kinerja penelitian yang dilaksanakan pada siklus 1 , 2, dan 3 disajikan pada Tabel 11.

Tabel 11. Ketercapaian Indikator Kinerja PTK

\begin{tabular}{rccc}
\hline Siklus & $\begin{array}{c}\text { Siswa Kriteria Tinggi/ } \\
\text { Sangat Tinggi(\%) }\end{array}$ & $\begin{array}{c}\text { Indikator } \\
\text { Kinerja }\end{array}$ & Indikator Kinerja \\
\hline 1 & $52,4 \%$ & $80 \%$ & Belum Tercapai \\
2 & $57,1 \%$ & $80 \%$ & Belum Tercapai \\
3 & $80,9 \%$ & $80 \%$ & Tercapai \\
\hline
\end{tabular}

Berdasarkan pada data Tabel 11 tersebut dapat diketahu bahwa pada siklus 1 dan 2 tingkat kepercayaan diri siswa mengalami peningkatan namun masih belum dapat memenuhi ketercapaian indikator kinerja penelitian yang ditetapkan yaitu sebesar $80 \%$. Pada siklus ketiga, 
indikator kinerja mencapai sebesar 80,9\% siswa telah memiliki kepercayaan diri yang tinggi, dengan demikian sudah memenuhi indikator kinerja penelitian yang ditetapkan sebesar $80 \%$.

\section{SIMPULAN}

Simpulan dari penelitian tindakan kelas ini adalah: (1) Implementasi strategi TWI dalam pembelajaran Pengolahan Masakan Kontinental siklus 1 termasuk dalam kriteria sedang (rerata 2,40), siklus 2 adalah tinggi (rerata 2,64), sedang siklus 3 termasuk dalam kriteria tinggi (rerata 2,78), menunjukkan terjadi peningkatan aktivitas siswa dari siklus pertama ke siklus selanjutnya. (2) Kepercayaan diri siswa siklus 1 termasuk sedang (rerata 2,49), siklus 2 termasuk tinggi (rerata 2,66), dan siklus 3 juga tinggi (rerata 2,86), menunjukkan terjadi kenaikan kepercayaan diri siswa dari siklus pertama ke siklus selanjutnya. (3) Implementasi strategi TWI terbukti dapat memperbaiki kepercayaan diri siswa kelas XI Jasa Boga 1 SMKN 1 Sewon Tahun 2015 dalam pembelajaran Pengolahan Masakan Kontinental (4) Indikator kinerja PTK yang ditetapkan, yaitu minimal $80 \%$ siswa memiliki kepercayaan diri tinggi, telah tercapai pada siklus 3 di mana terdapat $80,9 \%$ siswa yang memiliki kepercayaan diri tinggi. Berdasarkan hasil penelitian ini disampaikan saran: (1) Agar pembelajaran dapat berjalan lancar, proses cepat, merangsang siswa untuk aktif, maka sebaiknya persiapan alat, bahan dan sebagian proses yang sudah dikuasai siswa, dilakukan sebelum pelajaran dimulai. Persiapan ini terutama ditujukan untuk memperlancar proses peragaan dan peniruan. Bilamana memungkin kan persiapan dilakukan juga untuk tahap praktik. (2) Agar kegiatan peragaan yang dilakukan oleh guru dapat diikuti dengan baik oleh semua siswa, maka sebaiknya tempat peragaan guru ditata di tengah atau dipilih tempat yang memungkinkan semua siswa dapat dengan nyaman mengakses kegiatan tersebut.

\section{DAFTAR RUJUKAN}

Made Wena. 2014. Strategi Pembelajaran Inovatif Kontemporer, Suatu Tinjauan Konseptuan Operasional. Jakarta: PT Bumi Aksara

M. Nur Ghufron \& Rini Risnawita S. 2014. Teori-teori Psikologi.Yogyakarta: ArRuzz Media

Nirwana. 2013. Konsep Diri, Pola Asuh Orang Tua Demokratis dan Kepercayaan Diri Siswa. Persona, Jurnal Psikologi Indonesia, Pasca Sarjana Untag Surabaya. Mei 2013. Vol. 2. No. 2, hal 153 - 161

Pardjono. 2007. Panduan Penelitian Tindakan Kelas. Yogyakarta: Lembaga Penelitian UNY

Siti Nur Deva Rachman. 2010. Hubungan Tingkat Rasa Percaya Diri dengan Hasil Belajar (Studi Mapel IPS di SMP Fatahilah, Jakarta Selatan. Tesis. Jakarta: Jurusan Ilmu Pendidikan sosial FITK UIN Syarif Hidayatullah 